\title{
STUDIES ON THE OSPEDALE MAGGIORE AND SOME CRUCIFORM HOSPITALS IN LOMBARDY
}

by KENICHIRO HIDAKA*, Member of A.I.J.

One of the most impressive and characteristic features of Filarete's ingenious design of the Ospedale Maggiore may be the layout of the geometrical wards in the form of Greek cross (Fig. 1) ${ }^{1}$. Hospital architecture after Filarete both in Italy and in other countries from Spain to England had been firmly united to this geometrical cross-shaped scheme for more than two hundred years ${ }^{2)}$. The conception of this scheme, however, cannot be ascribed exclusively to our Florentine architect. In her early. work on the Ospedale Maggiore, Biagetti briefly referred to some hospitals in Lombardy as a probable formal germ of Filarete's intuitive project ${ }^{23}$. The subject has recently been reviewed and developed in the dexterous work of Foster, who was preponderantly engrossed in figurative coincidence among the plan of the Ospedale Maggiore and that of other hospitals built both before and after Filarete ${ }^{4}$. To advance the discource, however, hospitals

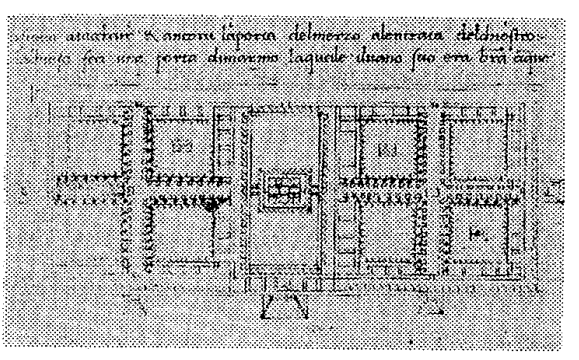

Fig. 1 Ospedale Maggiore, Milan. Plan. Codex Magliabechianus, Bk. XI, fol. $82 \mathrm{v}$. in Lombardy as well as in Tuscany should be once more thoroughly restudied here.

On March 8, 1449 Nicholas V gave papal permission to the erection of a new hospital at Mantua ${ }^{5)}$. The construction of the hospital, the Ospedale di San Leonardo, was started in the next year, when the architect, Luca Fancelli, arrived at the court of Ludovico II Gonzaga to direct the work ${ }^{6}$. The hospital of Mantua thus preceded by several years the Ospedale Maggiore, the construction of which probably began from 1456 to $1457^{\text {) }}$. Though decisive documents to clarify each phase of the construction are lamentably lacking, the hospital of Mantua was ready to receive the patient as early as March $1472^{8)}$.

According to Carpeggiani, Paolo Pozzzo's plan of 1787 (Fig. 2) shows the original four arms forming a cross with four square courts seperated by them and with outer buildigs forming a square $^{9)}$. The three arms of the cross with their entrance hall are by and large equal in size. Relatively short is the fourth arm, as it does not reach the exterior wall of the encircling outer buildings nor does it have any projecting vestibule ${ }^{10)}$. The fourth court, where the loggia was never built, perhaps served a different purpose from that of the other courts. The two storied loggia of the courts, unlike the Ospedale Maggiore, is made up of columns oddly linked together with arches on the ground floor and

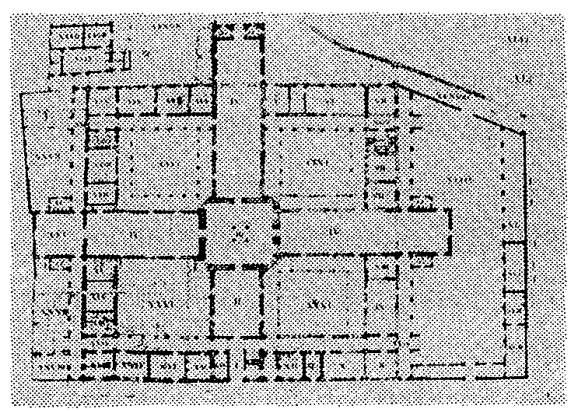

Fig. 2 Ospedale di San Leonardo, Mantua. Plan. by Paolo Pozzo (1787). of Ionian columns sustaining a streight architrave on the upper floor (Fig. 3) ${ }^{11}$. This loggia of Fancelli is Tuscan in its entirety and may have been akin, for example, to Chiostro Grande of Florentine Santa Croce (finished $1453 \mathrm{ca}$.). Despite the asymmetric arm with the diverted court, the marked singularity of this project could have been indubitably regarded as a vigorous rival both by the patron and by the architect of the Ospedale Maggiore.

Between the court of Milan and that of Mantua there existed strong ligaments. It is well docu-

\footnotetext{
* Post-doctoral fellow of J.S.P.S. (Univ. of Tokyo)
} 
mented that Francesco Sforza took a special interest in arranging an alliance with Ludovico II Gonzaga through the marriage of his son, Galeazzo Maria'i2). The duchess, Bianca Maria of Visconti, who was devoted to the erection of the hospital of Milan ${ }^{13)}$, and Barbara of Brandenburg, wife of Ludovico, provided another stable bond which might be more private and friendly between the two families $^{14)}$. That Filarete stayed at Mantua is evident from a passage of his Trattato di architettura where he refers to the covered bridge of Porta Molina ${ }^{15}$.

The possible influence of Mantuan hospital upon the project of the Ospedale Maggiore seems to be alluded more clearly. when Filarete mentions to a visit of an erudite lord ${ }^{16)}$, who has been identified with Ludovico by Spencer ${ }^{17)}$. In this part of Filarete's treatise an important and purposive laudation on the classical architecture, lined with a severe criticism of contemporary practices, is put forward in the mouth of this learned duke by proxy to the author himself. The passege is very much suggestive of a certain influence given by Ludovico to Francesco and Filarete. In addition, always following the narrative of Filarete, Ludovico was one of the honorable guests who attended to the solemn dedication ceremony of the Ospedale Maggiore ${ }^{18)}$. It would be quite improper to suppose that the planning and construction of the Ospedale di San Leonardo was disregarded totally by Filarete and his patron, both eagerly

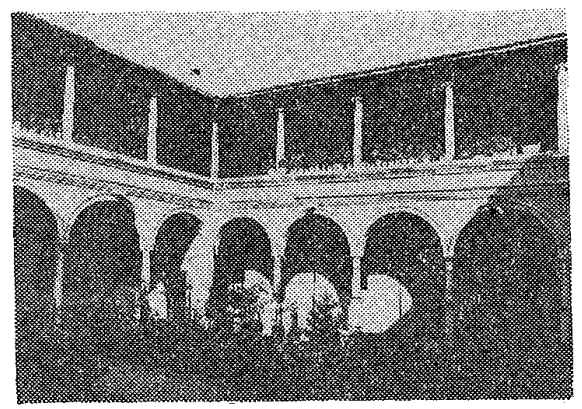

Fig. 3 Ospedale di San Leonardo, Mantua. Loggia. by Carpeggiani.

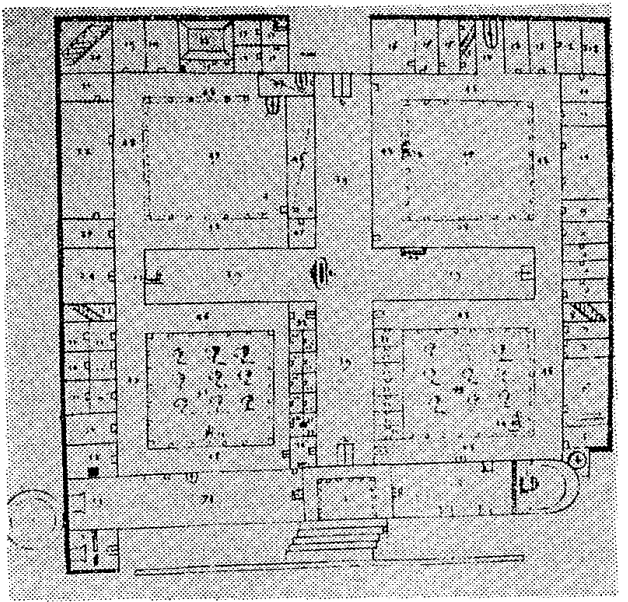

Fig. 4 Ospedale di San Matteo, Pavia. Plan. Archivio Ospedaliero of Pavia. undated. searching for a new solution to their own hospital under contemplation.

In 1448, local celebrities of Pavia, moved by a sermon of Domenico da Catalogna, decided to build a new hospital, that is, the Ospedale di San Matteo of Pavia (Fig. 4) ${ }^{19}$. Extremely significant is the fact that it was Francesco Sforza who, in February 1449, donated his ducal estate at Pavia for the new hospital ${ }^{20}$. On June 29, 1449, the bishop of Pavia, Giacomo Borromeo laid a foundation stone, though it was not documented who was the architect of this ingenious fabric ${ }^{21)}$. On September 13 , 1449 , six months after the bull addressed to the Ospedale di San Leonardo, the pope Nicholas $V$ authorized the construction of the Ospedale di San $\mathrm{Matteo}^{22)}$. Here, Nicholas V specified some details of the hospital to be built, ordering that the fabric must be the one with chapels, campanili, cloister courts and a cemetry for the poor ${ }^{28)}$. The pope, however, may not have been contented with this abstruct specification. In the appendix attached to the bull, he added that the hospital of Pavia must be realized "in the style of the hospital of Florence and that of Siena"24). These two Tuscan hospitals may well be identified with the Ospedale di Santa Maria Nuova of Florence and the Ospedale di Santa Maria della Scala of Siena.

The construction of the Ospedale di Santa Maria Nuova (Fig. 5) was made possible through generous donation of Folcro Poltinari of his estate near the church of Sant'Egidio in the year of $1286^{25)}$. In 1296, the church of Sant'Egidio with its cloister courts and gardens became linked together with the hospital which had been completed as a longitudinal building in $1288^{26)}$. The connecting part between the church and the hospital was accidentally

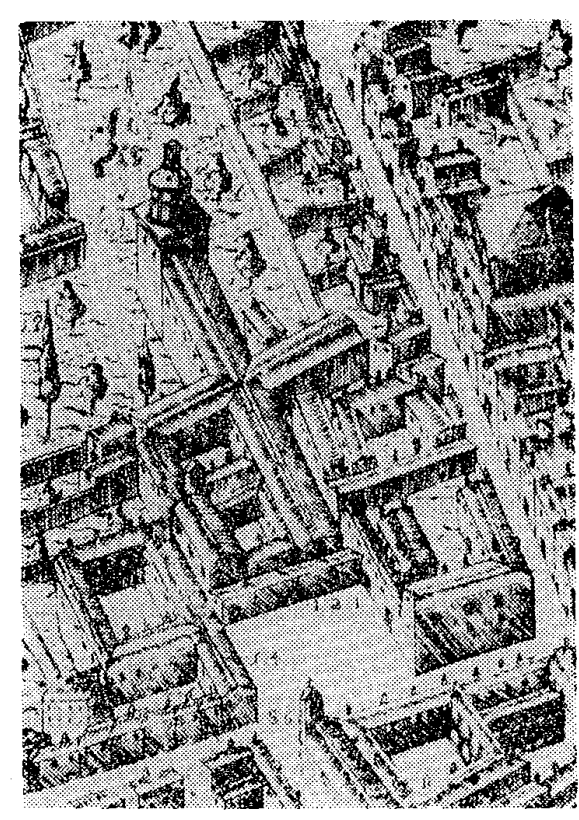

Fig. 5 Ospedale di Santa Maria Nuova, Florence. by Stefano Bonsignori (1584). 
illustrated in the manuscript of Marco di Bartolommeo Rustici (1448 ca.) (Fig. 6) ${ }^{27)}$. Then, from 1313 to 1315 , the original longitudinal ward was extended toward Piazza della Santa Maria Nuova to be a south arm of the future $\operatorname{cross}^{28)}$. From 1332 to 1348 the eastern arm of the future cross was built under the direction of Orlando Perozzi ${ }^{29)}$. However, it was not until 1479 that the western arm of the cross was finished ${ }^{30)}$. The construction of the northern arm seemed to be undertaken soon after the fulfillment of the western arm and that arm was brought to completion as late as the $1570{ }^{\prime} \mathrm{s}^{31)}$.

These briefest chronology would be sufficient to prove that the Florentine hospital in the age of Nicholas $\mathrm{V}$ could not be in the form of Greek cross. The drawing in the manuscript of Marco di Bartolommeo Rustici (Fig. 6) may assume considerable documentary importance ${ }^{32)}$. The rear part of the church and the hospital communicate by means of hallways used as a ward. The square court of Michelozzo (from 1420 to 1430) is properly drawn between the hospital and the $\operatorname{church}^{33)}$. Neither the western ward nor the cloister court in front of it is to be seen in this little drawing. Therefore the western arm probably yet remained to be constructed.

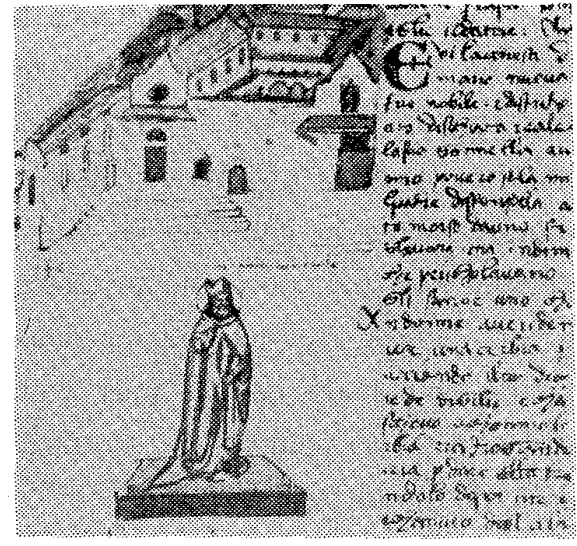

Fig. 6 The church of Sant'Egidio and the Ospedale di Santa Maria Nuova, Florence. by Marco di Bartolommeo Rustici (1448 ca.).

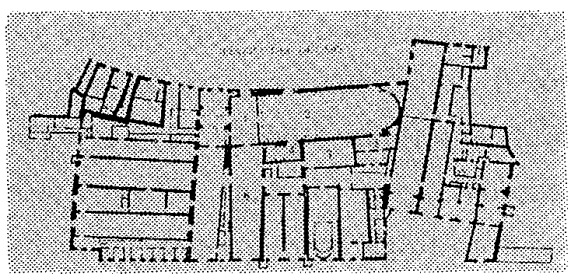

Fig. 7 Ospedale di Santa Maria della Scala, Siena. Plan. by Foster.

The Ospedale di Santa Maria della Scala of Siena (Fig. 7) dates as far back as 1186, when Urban III sanctioned the construction of a building to a certain monastic order ${ }^{34)}$. Concerning the present discussion, however, we need not scrutinize the long history of the hospital. Though enlargement works of the late fifteenth century altered the original structure, the long hallway of 'pellegrinaio', perpendicular to the Piazza del Duomo, must go back to '300 ${ }^{35)}$. As Foster has already clarified, the elongated ward of the hospital has its origin in monastic buildings such as the corridor apportioned for medical services in the Abbazia di Fossanova ${ }^{36)}$. Here at Siena, nothing indicates that the hospital once had or would have something like a cruciform wards embroidered with cloisters facing on square courts. The square court not being introduced to revive the medieval ward, the Ospedale di Santa Maria della Scala could be undoubtedly becoming obsolete in the course of the fifteenth century. The document about Filarete's visit to Florence and Siena is informative. In June, 1456, Francesco Sforza, probably moved by a certain traditional fame attributed to Tuscan hospitals ${ }^{37}$, dispached Filarete and Giovanni di Sant'Ambrogio to these Tuscan cities for necessary preparative studies ${ }^{38)}$. On the contrary, as is shown pointedly in a letter of Giovanni de' Medici, they found nothing preeminent in the hospitals at Florence and at Siena ${ }^{39)}$. The plans Giovanni sent to Milan ${ }^{40)}$ as well as the plan of the Ospedale di Santa Maria Nuova itself were likewise rejected on the part of Francesco Sforza ${ }^{41)}$. It was quite natural of him to do so after he had seen the well-ordered hospital of Pavia completed admirably during these very years.

Various contemporary documents bear witness to the assiduous construction of the Pavian hospital from 1451 to 1455 , referring to it from time to time as "nuper inceptum et nondum perfectum (recently started and not yet completed)" or as "iam magnis hedificis erectum (a grand edifice now erected)" ${ }_{42}$. As the patient were received for the first time in 1456, the hospital indubitably had been next to completion by this time, though it was finally completed as inexplicably late as $1513^{43}$. The whole fabric was intentionally controlled to form Greek cross inscribed in a square in the plan (Fig. 4). Gauging the medieval hospitals in Tuscany, Filarete, who had stayed at Pavia ${ }^{44)}$, soon understood that the project of the anonymous architect in the Ospedale di San Matteo had been far superior to those appeared in the prescriptive specification of the pope. 
The striking correspondence between the hospital of Pavia and that of Milan, however, should not be limited to the congruity of the intrinsic figure of their wards. They also have in common befitting loggias of two stories alongside of the intersecting wards, though at Pavia columns on the upper story are accentually slenderized and therefore the progression of arches is less wavy (Fig. $8,9)$. These two storied loggias, parallel to the main buildings facing on square courts, may well have originated from monastic architecture in central and northern Italy. However, in the Ospedale di Santa Maria Nuova the two storied loggias as is seen in ex-Priory of Oblates (fourteenth century) or in Badia Fiorentina (so-called Chiostro degli Aranci by B. Rossellino, 1435-40) was never introduced into the original or additional buildings. To put it another way, the intersecting wards of Santa Maria Nuova, not being inscribed in outer square buildings, may have been created, as it were, for convenience sake only. Owing to default of encircling square buildings to keep inner courts, the wards casually opened upon gardens in the north and casually faced upon annexed buildings in the south (Fig. 5). The same holds good of other minor Florentine hospitals of those days such as the Ospedale di San Matteo (homonymous to the Pavian hospital) ${ }^{45}$.

In Lombardy, however, the very contrary was the case. The Ospedale di San Luca of Brescia, now destroyed, offers another intriguing and the earliest example. The construction of the hospital was started in 1447 by an anonymous architect and the first patient were received in $1452^{46)}$. Cruciform wards with four square courts bounded by outer buildings seem in all probability to have been provided in the earliest project ${ }^{47)}$, though the fourth arm was added with other subsidiary buildings as late as 1821 by Vigliani ${ }^{48}$. . An engraving of the late eighteenth century by G.B.

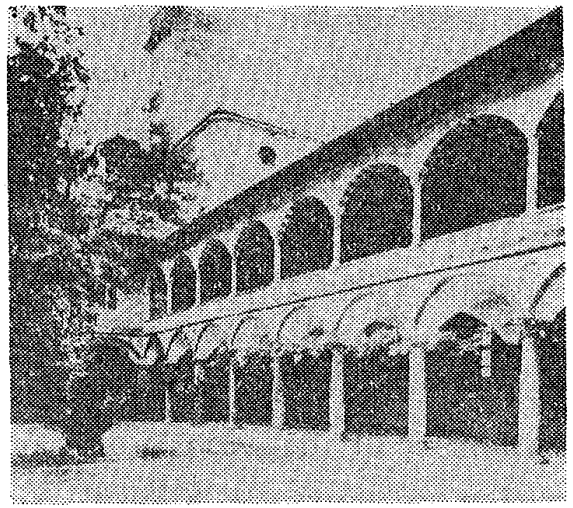

Fig. 8 Ospedale di San Matteo, Pavia. Loggia. from a post-card.

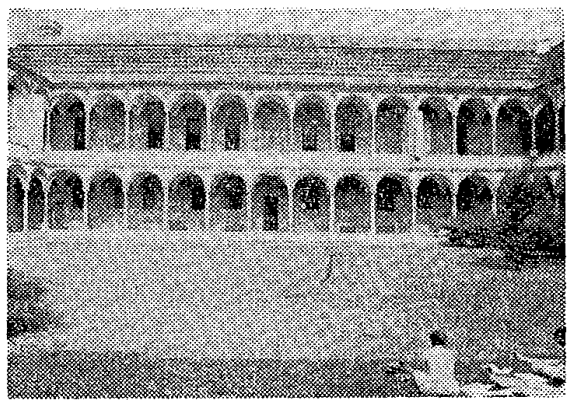

Fig. 9 Ospedale Maggiore (now University of Milan). Loggia.

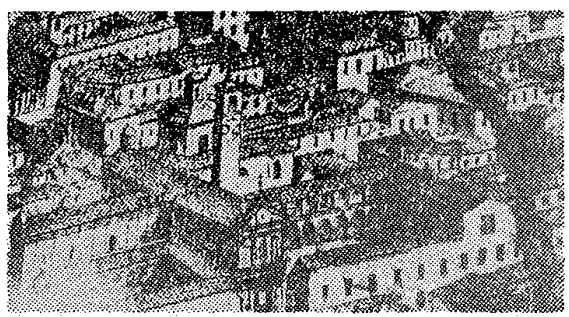

Fig. 10 Ospedale di San Luca, Brescia. by G.B. Carboni (XVIIIc.).

Carboni offers a general view of the hospital which had been still vestigial of the original two storied loggias despite later additions (Fig. 10) ${ }^{49}$. A letter dated April 2, 1456, now in the Archivio dell' Ospedale di Brescia, proves that certain administrators of the ducal court at Milan were sent to Brescia to study this propitious model ${ }^{50)}$. Admittedly Francesco Sforza could by no means pretermit the alluring structure at Brescia.

Cremona, where Francesco and Bianca Maria were married in 1441, had been united to the dominion of the Sforza's as a dowry city of the duchess, who provided intimate rapports through religious achievements between the ducal court at Milan and the city on the $\mathrm{Po}^{51)}$. It is really a matter for regret that documents on the Ospedale di Santa Maria della Pietà of Cremona are lacking desperately ${ }^{52}$. The construction of the hospital was likely started in the early years of the 1450's, or more probably from 1451 to $1452^{532}$. A schematic plan of 1583 (Fig. 11), first published by Campi ${ }^{541}$ and recently reproduced by Foster ${ }^{55}$, represents disfigured cross-shaped wards with adjacent courts, two of which are degenerated. None the less clear is the intention of an anonymous architect to encircle the whole complex with outer buildings in this case divided into so many cells. Whether the hospital of Cremona was originally attired with two

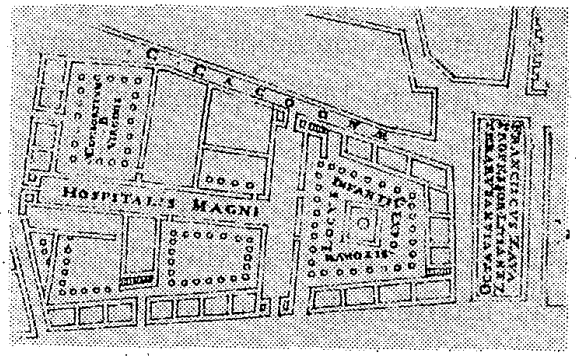

Fig. 11 Ospedale di Santa Maria della Pietà, Cremona. Plan. from a map of 1583. 
storied loggias or not still remains to be clarified in future restoration works of the existing structure altered and dilapidated disgracefully. A fabric of great interest in this hospital may be "locus infantium expositorum", that is, a foundling asylum to house orphans and children born out of wedlock. Documents are taciturn on this trapezoidal court located to the right of the main wards. Continuous row of small rooms, however, is indicative of the original boundary of the locus where the anonymous architect laid out adroitly both the cruciform wards and the suitable orphan home. The hospital of Cremona, though somewhat deformed, may offer an illustrative example in transition toward a more sophisticated variant of the cross-shaped wards studied by Filarete later at the Ospedale Maggiore.

It must be borne in mind that the hospitals of Pavia, Brescia and Cremona, all founded in the mid-fifteenth century, were commonly called with a prefix "Hospitalis Magni". In the statute issued on November 1, 1451, hospital of Pavia was authorized with a title of "Hospitalis Magni Sancti Matthaei Pietatis Papiae"56). The hospital of Brescia appeared in a deliberative document as "Hospitale unum magnum et generale fiat Brixiae"57). The Cremonean hospital was not in the least exceptional, as "Hospitalis Magni” is leggible in Campi's map of 1583 (Fig. 11) ${ }^{58)}$. The prefix, unconnected to the Tuscan hospitals, must have connoted that miserable asylums scattered in the city had been united into a new and grand hospital through the papal authorization ${ }^{59}$. At Brescia there was a growing tendency as early as the 1420's to save the poor and invalid left in the worst possible plight by means of con. structing a merged sanitary hospital ${ }^{60)}$. It is of great importance that religious orders, providing stable bonds with the Holy See at Rome, had been taking the initiative from the very beginning of this movement toward an erection of "Hospitalis Magni" "61). The same trend had been on the increase from 1448 onward at Pavia as well, where Domenico da Catalogna devoted his whole activities not only to the foundation but also to the administration of the hospital ${ }^{62)}$. At Cremona it was Timoteo Maffei (De Maffei da Verona) who preached eagerly on urgent needs of clinical services ${ }^{83}$.

On the back cover of his untitled work on the hospital of Milan, Gilino called the Ospedale Maggiore "hospitalis magni Mediolani" ${ }^{44)}$. In fact, thirty one hospitals in Milan were united to make the Ospedale Maggiore ${ }^{65)}$. Just as other hospitals at Pavia, Brescia and Cremona, religious power was on the move at Milan toward an erection of the hospital in parallel with a sagacious policy of Francesco Sforza ${ }^{66)}$. As a Franciscan confessor of Bianca Maria, Michele da Carcano here had been vigorously attending to the construction, allegedly prescribing the statute of the hospital ${ }^{67)}$. When the construction reached a crisis in 1465-1466 ${ }^{68}$, Michele who happened to be in Rome was to be responsible for the work to such a degree that he wrote a letter to the duchess to make her move toward recommencement of the intermitted construction ${ }^{69}$. In view of the great interest in religious flavor shown by Gilino, it is not surprising that Michele da Carcano was documented by him to have been a creator of the hospital along with the duke ${ }^{70)}$. But there is much more to it. All through his work Gilino would never mention Filarete at all. It must have been infallible for the chief secretary in the early sixteenth century that Filarete had been the architect of the hospital. Yet he passed it with silence. After having finished the introductory chapters on the commencement of the hospital, he proceeded promptly to describe the cruciform wards of the hospital. Admittedly Gilino thought it to be safer that cruciform wards had been introduced into Milan by the hand of Michele irrespectively of the caliber of Filarete. It is true the development of the study of cruciform wards reached its apogee at the hospital of Filarete who employed sedulously all the means at his disposal to afford 'spedale di poveri'. But, at the same time, yet much as the pedigree of the cruciform wards should be scurutinized in future, the crossshaped scheme in itself could have been rather independent of the genius of Filarete, whose legacy in this project will be assessed in my next work.

My research has been guided by Prof. Arnaldo Bruschi, who has given of his vast fund of knowledge about Renaissance architecture and to whom I must remain always indebted.

1). Antonio Averlino detto il Filarete, Trattato di architettura Codex Magliabechianus, National Library of Florence, 
II, I , 140 (hereafter cited as Filarete-Magliabechianus), Book (hereafter abbreviated to Bk.) XI, fols. 79 r-83v. Antonio Averlino detto il Filarete, Trattato di architettura, 2 vols, eds. A.M. Finoli \& L. Grassi, Milan, 1972 (hereafter cited as Finoli-Grassi, Trattato), pp. 298 322. J.R. Spencer, Filarete's Treatise on Architecture, 2 vols, New Haven, 1965 (herteafter cied as Spencer, Treatise), pp. 137 146. For a general description of the hospital of Filarete, see K. Hidaka, "The Ospedale Maggiore Described in the Treatise of Filarete and its Urbanistic Implication", Transactions of the Architectural Institute of Japan, n. 281 (1979 July).

2) Many examples, both constructed and unconstructed, demonstrate the decisive influences of Filarete's plan which continued for centuries until the cruciform wards became obsolete compared with the radial plan in the eighteenth century. For this argument of the diffusion of the wards in the form of Greek cross, see following contributions. S. Rovere, Relazione storica dell'Ospedale Maggiore di S. Giovanni Battista e della città di Torino, Turin, 1876. A. Timolati, L'ospitale Maggiore di Lodi, Lodi, 1883. R. Burnand, L'Hôtel Royal des Inva lides, 1670 1789, Paris-Nancy, 1913. G.C. Bascapè, "Il progresso dell'assistenz ospedaliera nel secolo XV e gli ospedali 〈a crociera〉", Tecnica Ospedaliera, 1936, fasc. 1 2. P. de Angelis, L'Ospedale apostolico di s. Spirito in Sassia, Roma, 1936. W. Lotz, "Entwürfe Sangallos und Peruzzis für S. Giacomo in Augusta in Rom", Mitteilungen des Kunsthistorischen Institutes in Florenz, V (1937 40). P.C. Carpaneto, Pammatone cinque secoli di vita ospedaliera, Genoa, 1953. R. Herringer, "Die Lazarette der beiden Furttenbach", Atti del XLV congresso internazionale di storia della medicina, II, Roma-Salerno, 1954, pp. 698 712. W.H. Godfrey, The English almshouse, London, 1957. D. Jetter, "Das Mailänder Ospedale Maggiore und der Kreuz förmige Krankengrundriß”, Sudhoffs Archiv für Geschichte der Medizin, XLIV (1960), pp. 64 75. Idem, "Hospitalgebäude in Spanien", Sudhoffs Archivfür Geschicte der Medizin, XLIV (1960), pp. 239 258. Idem, "Frankreichs Bemühen um bessere Hospitäler", Sudhoffs Archiv für Geschichte der Medizin, XLIV (1965), pp. 147, ff. D. Leistikow, Dieci secoli di storia degli edifici ospedalieriin Europa, Angelheim am Rhein, 1967. C. Wilkinson, The Hospital of Cardinal Tavera in Toledo. A Documentary and Stylistic Study of Spanish Architecture in the Sixteenth Century. Ph. D. Thesis at Yale University, 1968.

3) V. Biagetti, L'Ospedale Maggiore di Milano, Milan, 1937, (hereafter cited as Biagetti, Ospedale) pp. $24 \sim 41$.

4) P. Foster, "Per il disegno dell'Ospedale di Milano", Arte Lombarda: Il Filarete. Atti del Corso di Specializzazione, n. 38/39, Milan, 1973, (hereafter cited as Foster, disegno) pp. 1 22,

5) E. Marani and C. Perina, Mantova : Le Arti, vol. II, Mantua, 1961, pp. 67 70, 103 104.

6) The contemporary chronicle of Andrea Schivenoglia reads; "de lanno 1450 fo principiato uno hospedallo de San Lonardo in Mantoa e qualo fo ditto chel sara uno di bellyo spedally de Tallia..." (A. Schivenoglia, Cronaca di Mantova. Manuscript now in the Biblioteca Comunale at Mantova, 1.1.2. fol. 20v). Carpeggiani has recently shown in a series of indefatigable works that the architect of the hospital could be none other than Luca Fancelli who arrived at the court of the Gonzaga's in 1450 with a letter of recommendation of Cosimo de' Medici the Old. See, P. Carpeggiani, "Luca Fancelli architetto civile nel contado mantovano : ipotesi e proposte", Civiltà Mantovana, IV (1969) n. 20, pp. 87 114. Idem, "Luca Fancelli architetto civile nel contado Gonzaghesco", Arte Lombarda, XVI (1971), pp. 37 44. Idem, "Congruenza e parallelismi nell'architettura lombarda della seconda metà del '400 : il Filarete e Luca Fancelli", Arte Lombarda: Il Filarete. Attidel Corso di Specializzazione, n. 38/39, Milan, 1973, (hereafter cited as Carpeggiani, Fancelli), pp. 53 69. Cf. Foster, disegno, p. 8, p. 17, figs. 16,17 .

7) For the history of the Ospedale Maggiore prior to the construction, see, K. Hidaka, "A Preliminary Study on the Ospedale Maggiore of Antonio Averlino called Filarete", Transactions of the Architectural Institute of Japan n. 280, (1979 June).

8) "...de lo mexo de marzo 1472 lospedallo Grando de Mantova comenzoe [=comincia] alozare [=a locare] di pouery..." (A. Schivenoglia, Cronaca di Mantova, fol. 69r.).

9) Carpeggiani, Fancelli, p. 55. The plan which is now conserved in Archivio di Stato at Mantua was photographed and reproduced by Carpeggiani, (Carpeggiani, Fancelli, p. 60, fig. 1).

10) In Giuseppe Ranieri's map of Mantua in 1831, the hospital is given a complete Greek cross in the plan. However, we are not sure whether such a schematic drawing in the large map could represent the real state of the building with reliability.

11) Cf. Foster, disegno, p. 8, n. 73, p. 17, fig. 17, and Carpeggiani, Fancelli, p. 55, n. 24.

12) The marriage of convenience, as is generally known, was dissolved before an ambitious desire of Francesco who aimed at making a new rapprochement with the royal house of France. For fuller information on the game of marriage between the two families, see, S. Davari, "Il matrimonio di Dorotea Gonzaga con Galeazzo Maria Sforza", Giornale ligustico di archeologia, storia e letteratura, XVI (1889), fasc. 1, pp. 363 90, and L. Beltrami, "L'Annulamento del contratto di matrimonio fra Galeazzo Maria Sforza e Borotea Gonzaga, 1463", Archivio storico lombardo, XVI (1889), fasc. 1, pp. 126 32.

13) M. Lazzaloni and A. Muñoz, Filarete, scultore e architetto del secole XV, Rome, 1908, p. 186.

14) Cf. Spencer, Treatise, p. 174, n. 13.

15) Filarete-Magliabechianus, Bk. XIII, fol. 93 v, Finoli-Grassi, Trattato, p. 356, Spencer, Treatise, p. 162, “It is true, I did see the one at Pavia and the very long one at Mantua". (translation by Spencer).

16) Filarete-Magliabechianus, Bk. XIII, fols. $99 \mathrm{v} \sim 100$ r, Finoli-Grassi, Trattato, pp. 379 380, Spencer, Treatise, pp. 174 175. "Then my lord turned to another lord who had come with him out of love and goodwill and, perhaps, because of other matters between them. He seemed to me to be a most educated man in many things and especially in architecture. $\cdots$ They spoke together for a while about my deeds. All the way to the city they talked of nothing but architecture..." (translation by Spencer).

17) J.R. Spencer, "La datazione del trattato del Filarete desunta dal suo esame interno", Rivista d,Arte, XXXI (1958), 
pp. 93 103. Cf. Spencer, Treatise, p. 174, n. 13.

18) Filarete-Magliabechianus, Bk. XI, fol. 83 v, Finoli-Grassi, Trattato, p. 319, Spencer, Treatise, p. 145.

19) For the Ospedale di San Matteo of Pavia, see following contributions; C. Robolini, Notizie appartenenti alla storia della sua Patria, Pavia, 1828, G. Giardini, Memorie topografiche, Pavia, 1830, P. Magenta, Ricerche su le pie fondazioni e su l,ufficio loro a solievo dei poveri, con una appendice sui pubblici stabilimenti di beneficenza della città di Pavia, Pavia, 1838, R. Soriga, Pii sodalizi laicali in Pavia Medioevale, Pavia, 1929, L'Ospedale Policlinico di S. Matteo di Pavia, Pavia, 1933 (especially, Parte I, Notizie storiche), C. Saletti, "La fabbrica auatirocentesca dell'Ospedale di San Matteo in Pavia", Arte Lombarda, V (1960), pp. 48 55, Foster, disegno, p. 7, Carpeggiani, Fancelli, p. 55.

20) P. Magenta, op. cit, p. 37. Cf. Foster, disegno, p. 7.

21) L'Ospedale Policlinico di S. Matteo di Pavia. op. cit, Parte I, Notizie storiche, p. 6. According to Carpeggiani, Martion Fugazza provided a desing of the hospital but no documentary proofs were given for this hypothesis. See, Carpeggiani, Fancelli, p. 55 and n. 26.

22) P. Magenta, op. cit, passim (especially, appendix on pp. $40 \mathrm{ff}$.$) .$

23) P. Magenta, op. cit, appendix on pp. $40 \mathrm{ff}$

24) "ad instar Floventinensis et Senensis hospitalium" (ibid.) The specification referring to the Ospedale di Santa Maria Nuova at Flolence and to the Ospedale di Santa Maria della Scala at Siena was once more repeated in the confirmation to the bull in 1452 ("unum magnum et grande Hospitale - erectum ad instar senensis et florentinensis Hospitalium"). Cf. Foster, disegno, p. 7, Carpeggiani, Fancelli, p. 55.

25) G. Pampaloni, Lo spendale di S. Maria Nuova e la costruzione del loggiato di Bernardo Buontalenti ora. completato della Cassa di Risparmio di Firenze, Firenze, 1961, pp. 5 7. For the history of the Florentine hospital of Santa Maria Nuova see also, M. Covoni Gerolami, Regolamento dei Regi Spedali di S. Maria Nuova e S. Bonifazio in Firenze, Florence, 1789 and O. Andreucci, Della Biblioteca e Pinacoteca dell'Arcispedale di S. Maria Nuova in Firenze, Florence, 1871.

26) G. Pampaloni, op. cit, pp. 6 15.

27) The manuscript, now in the Biblioteca del Seminario Maggiore was reproduced totaly in G. Fanelli, Firenze Architettura e città, 2 vols., Florence, 1973. For the drawing in question see, ibid. vol. 2, p. 65, fig. 376.

28) L. Passerini, Storia degli stabilimenti di beneficienะa e d'istruzione elementare gratuita della città di Firenze, Florence, 1853, p. 354. Cf. Pampaloni, op. cit, p. 19.

29.) The untitled short 'storia' by anonymous author of 1662, now in the Archivio dell'Ospedale di Santa Maria Nuova and published by Pampaloni, reads “...prolungò detto spedale sino alla croce che si vede di presente con farli il braccio destro volto verso levante e confinante detto braccio con via della Pergola, si che lo spedale era in forma di sette e nella testata di corsia era l'altare, quale era posto sotto una cupoletta..." (Pampaloni, op. cit, p. 80 , n. 47). Cf. M. Covoni Gerolami, op. cit, p. XIX.

30) The 'storia' referred to in the preceding note reads "La crocie da llato sinistro dello spedale delli huomini di nuovo e dai primi fondamenti fu fatta et hedificata e compiuta interemente l'anno 1479" (Pampaloni, op. cit, p. 80, n. 48). Cf. Passerini, op. cit, p. 297.

31) O.D. Giglioli, "Alessandro Allori e lo spedale di S. Maria Nuova",Rivista d'Arte, IX (1916), pp. 258 259 and Pampaloni, op. cit, pp. 21 29 .

32) The authenticity of the codex has been already established. See, for example, A. Bruschi, "Considerazioni sulla Maniera matua del Brunelleschi", Palladio, XXII (1972), pp. 89 126 (especially theappendix, Ipotesi di ricostruzione grafica dell'al zato della Rotonda degli Angeli).

33) H. Saalman, "The Palazzo Comunale in Montepulciano. An unknown work by Michelozzo", Zeitschrift für Kunstgeschichte, XXVIII (1965), pp. 1 $\sim 46$.

34) Statuti senesi scritti in volgare ne' secoli XIII e XIV, ed. L. Bianchi, Bologna, 1887, XI. Almost.all the important documents are to be found in this volume edited by Bianchi as well as in Archivio dell'ospedale di S. Maria della Scala, ed. G. Cantucci and U. Morandi, Rome, 1960.

35) : Foster, disegno, p. 4.

36) Ibid.

37) Commendatory remarks on the Tuscan hospitals are to be found in various writings. As early as mid fourteenth century, Filiopo Villani jotted down in his chronicle: "Questi lasci di puesto spedale di Santa Maria Nuova si stribuirono assai bene, perroche lo spedale è di grande elemosina, e sempre abbonda di molti infermi uomini e femmine, $i$ auali sono serviti e curati con molta diligenza e abbondanza di buone cose da vivere, e da sovvenire a' malati, governandosi per uomini e femmine di santa vita" (Cronaca di Matteo e Filippo Villani con le vite d'uomini illustri fiorentini di Filippo e la Cronaca di dino Conpagni, Milan, 1834, pp. 4 5). Alberti declared: "Apud Etruriampro vetere illo sanctitatis et verissimae religionis cultu, auo semper claruit, mirifica visuntur hospitaria incredibili habita impensa, ubi civium peregrinorumve puivis nullam, puae ad salutem pertineat, rem sibi defuturam sentiat (In Toscana, terra di antichissime tradizioni di pietà religiosa, in cui sempre di distinse, si travano splendide case di cura, approntate con spese ingentissime, dove pualsiasi cittadino o straniero trova pualunpue cosa possa servire alla suasalute)". (De re aedificatoria, ed. G. Orlandi with translation into Italian, Milan, 1966, V-viii, p. 369). Luther's laudatory remark on Tuscan hospitals was cited in A. Canezza, Note illustrative alla Mostra Storica degli Ospedali Italiani, Rome, 1935, pp. 45 \& 107.

38) N. Lazzaloni and A. Muñoz, op. cit, p. 186. See also, J.R. Spencer, "Two new documents on the Ospedale Maggiore, Milan and Filarete", Arte Lombarda, XVI (1971), pp. 114 116 and my short work cited above in the note 6 . The additional specification of Nicholas $\mathrm{V}$ in the bull addressed to the hospital of Pavia perhaps played a certain tain role in the decision of Francesco Sforza to send the architect to Tuscana. 
39) The letter, dated 25, June, 1456, was written by Giovanni de' Medici in reply to a letter of recommendation directed to him from Francesco Sforza and dated in its turn 4 June, 1456. After the usual salutations it reads: "Esuto pui Maestro Antonio della ilpuale ma narrato come la Illustrissime Vostra Signoria vole dare ordine a fare puello spedale diche altrevolte costa ragionamo. Et perche lu nabbia qualche buono exemplo Io glo fatto vedere tutto il nostro aui di Sancta Maria nuova che e gran cosa et degna. Di poi luj se partito sença fare meco altra conclusione...Et perche aui sono Maestrj assai et Valentissimi Io ho ordinato farne fare piu et diversi modellj a ciaschuno etqueglj mandero alla V.S. accio che possa examinarglij et prendoro poi quello glandra meglo per lanimo..." (Milan, Ambrosiana Library, Class Z Sup. 247, fol. 200, publisched by Spencer in Two new documents, op. cit, p. 115).

40) In the letter cited in the precedent note, Giovanni de' Medici, somewhat piqued at Filarete's dissatisfaction with the Florentine hospital, added that he made certain architects draw some projects for the hospital of Milan to cope with one by Filarete. The existence of theseprojects is not known. Spencer imagined that about these projects "probably Michelozzo, Antonio Manetti, Bernardo Rossellino and perhaps even Alberti were consulted" (J.R. Spencer, Two new documents,op. cit, p. 115).

41) J.R. Spencer, Two new documents op. cit, p. 115. Filarete himself referred to the dissatisfaction of Francesco with the hospitals of Florence and of Siena. See, Filarete-Magliabechianus, Bk. Xl, fol. $79 \mathrm{v}$, Finoli-grassi, Trattato, pp. 299 300, Spencer, Treatise, p. 137.

42) P. Magenta, op. cit, appendix, pp. 35 37. C. Saletti, op. cit, passim.

43) “Nel 1513, l'ospedale era compiuto nell'intera fabbrica in forma di croce, in mézzo a cui sorgeva l'altare, costruito in guisa che tutti gli infermi giacenti nelle quattro infermiere potevano scorgere il sacerdote celebrante ed ascoltare la Messa" (Giardini, op. cit, p. 47).

44) See above note 16. In the sixteenth book of the treatise, Filarete mentions an excursion to the city of Avipa and Zacempia, evidently an anagram of Pavia and of Piacenza respectively (Filarete-Magliabechianus, Bk. XVI, fol. 125 v, Finoli-Grassi, Trattato, pp. 470 471, Spencer, Treatise, pp. 217 218).

45) Passerini, op. cit, pp. 149 160, 816 823.

46) For the history of the Ospedale di San Luca of Brescia see, G. Bonelli, L'Archivio del Vecchio Ospedale di Brescia, 1916, Brescia, and L.F. d'Ostiani, Storia, tradizione ed arte nelle vie di Brescia, Brescia, 1927. Cf. Biagetti, Ospedale, pp. 35 37.

47) In contemporary documents, the hospital was often referred to as "crociera di San Luca". Cf. Biagetti, Ospedale, pp. 35 37, L. Grassi, La Ca'Granda, storia e restauro, Milan, 1958, p. 64 and Foster, disegno, p. 7.

48) Il nuovo ospedale di Brescia, Brescia, 1935, Parte I, Notozie storiche, passim. Cf. Biagetti, Ospedale, p. 37.

49) The engraving was published for the first time in L.F. d'Ostiani, op. cit, p. 682 and was republished by Foster in Foster, disegno, p. 16, fig. 13.

50) G. Bonelli, op. cit, p. 9 and Biagetti, Ospedale, p. 35 . The writer has not yet consulted directly this letter. According to Biagetti, the Ospedale di San Luca is described in this letter as "pulchrum et ordinatum" (loc. cit.).

51) Filarete himself could have been another link of the chain binding the Sforza court and Cremona. He played an important role at least at the first phase of the reconstruction program of old San Gigismondo outside the city of Cremona. The rebuilding work of the church, however, was started as late as June 10, 1463 probably under the direction of Bartolomeo Gadio (or Gazzo da Cremona), who had been in the anti-Filarete camp among masters in Lombardy (G. Galeati, La chiesa di S. Gigismondo presso Cremona, Cremona, 1913, pp. 24 25). Neverthless, the church of San Gigismondo, the project of which might have been ready at the hand of Filarete, should be restudied in connection with a church described in the sixteenth book of Filarete's treatise (FilareteMagliabechianus, Bk. XVI, fols. 122 v ff., Finoli-Grassi, Trattato, pp. 458 ff., Spencer, Treatise, pp. 212 ff.). Cf. Finoli-Grassi, Trattato, p. 458, n. 1, Spencer, Treatise, p. 212, n. 1 and J.R. Spencer, "La datazione...", od. cit, pp. $99 \sim 100$.

52) The writer, to his great regret, has not yet obtained any copy of Antonio Campi, Cremona fedelissima città et nobilissima colonia de' Romani rappresentata in disegno col suo contato, et illustrata d'una breve historia delle cose più notabili appartenenti ad essa, Milan, 1645. For a brief description of the hospital of Cremona see, Consiglio degli Istituti Ospitalieri di Cremona, Rapporto al Consiglio Ospitaliero, Cremona, 1909, p. 5.

53) In May 1451, Nicholas V approved the constrction of the hospital (Consiglio degli Istituti Ospitalieri di Cremona, op. cit, p. 5).

54) See above note 52 .

55) Foster, disegno, p. 17, fig. 18.

56) L'Ospedale Policlinico di S. Matteo di Pavia, op. cit, p. 7 and Biagetti, Ospedale, p. 20, n. 15.

57) G. Bonelli, op. cit, p. 9 and Biagetti, Ospedale, p. 19, n. 14.

58) See above note 52 .

59) By the way, the Ospedale di San Leonardo was referred to as "lospedallo Grando de Mantoa" in the manuscript of A. Schivenoglia mentioned above in note 6 .

60) L.F. d'Ostiani, op. cit, p. 75.

61) It was on December 12, 1445, when confraternities of Santo Spirito of Brescia reauested the Holy See to sanction them a foundation of a new hospital under the name of San Luca, in corporating a homonymous church with annexed gardens. In answer to the request, the pope Eugenio IV authorized the construction on May 7, and additionally on November 10,1446 "sub vocabulo Sancti Spiritus et Sancti Lucae de Misericordia in civitate Brixiense". (Il nuovo ospedale di Brescia, op. cit, Parte I, Notizie storiche).

62) As is stated above, the Dominican preacher persuaded Pavian people into constructing a new hospital. He him- 
self had been full in activity to solicit contributions for the construction (L'Ospedale Policlinico di S. Matteo di Pavia, op. cit, p. 6). He also made every effort to receive a generous sanction of the pope Nicholas V who gave certain privileges to the hospital (ibid. p. 7). In addition it was he that composed "Statua constitutiones et ordinationes Venelabilis Societatis et Dedicatorum Hospitalis Magni Sancti Matthaei Pietatis Papiae" issued on November 1, 1451.

63) Consiglio degli Istituti Ospitalieri di Cremona, op. cit, p. 5.

64) Joannes Jacobus Gilinus, Ia Antiquar, Arx erat hic quodam domus est ubi \& hospita virgo/Qua: data pauperibus munera cuncta vides ...(End) Fundationis hospitalism magni Mediolani itê reformationis morem aliorum xenodochior ú annexorum $\cdots$, Milan, 1508. This work not being titled, I have followed the General Catalogue of British Library (701. f. 1(1)). The untitled pamphlet of Gilino (sometimes called "Fundatio magni hospitalis mediolani" for convenience) was published both in Italian and in Latin editions at the same time (on September 4, 1508), of which the Italian edition was republished by Spinelli (S. Spinelli, "Gian Giacomo Gilino. Relazione ai Deputati dell'Ospedale Grande di Milano", L'Ospedale Maggiore, XXIV (1936); nn. 8, 9, 10). The book of Gilino is of great rarity. A copy of Latin edition is to be found at Biblioteca Ambrosiana, Biblioteca di Brera, Archivio dell'Ospedale Maggiore, British Library and Staatsbibliothek in Berlin. There exist only two copies of the Italian version, each at Biblioteca Ambrosiana and Archivio dell'Ospedale Maggiore. Differences, sometimes distinguished not to say serious, do exist between the more complicated Latin version and the briefer Italian version, which made Spinelli consider that the latter might be an abbreviated translation of the other (Spinelli, op. cit, n. 8, p. 379). This work of Gilino, who had occupied 'Priore del Capitolo' of the Ospedale Maggiore in 1508, is the oldest printed book on the hospital and as such is of great consequence. Later works on the hospital of Milan, such as written by G. Morigga (Tesoro preciso de Milano, Milan, 1598), were based upon this fundamental work of Gilino. As a matter of course, "Ospedale Maggiore" was at first used as a prefix or probably as a certain byname which was not sufficient in itself. In two maps of Milan, dated 1469 and 1472 respectively, the hosppital of Milan was indicated as "dela nunciata". (see A. Ratti, Due piante iconografiche di Milano, Milan, 1902). Gilino himself named the hospital with a title of "uirgineæ annuntiationis" in the seventh chapter of the Latin edition ("Qui reformationis auctor fuerit : \& ubi eam tractauit", correspondent Italian title of "Annunciatione de la Virgine" appearing in the seventh chapter, "Del sito designato al hospitale grande et titulo sus", of the other edition).

65) P. Pecchiai (L'Ospedale Maggiore nella storia e nell'arte, Milan, 1927, pp. 134 147) drew up a list of these hospitals. On the other hand Lazzaroni and Muñoz held that hospitals incorporated to the Ospedale Maggiore were twenty-nine (M. Lazzaroni and A. Muñoz, op. cit, p. 183).

66) Before he entered into the city of Milan on February 25, 1450, Francesco, who had been so desirous to be the lord, gave a promise to the communal government of Milan that he would never reconstruct Castello di Porta Giovia (future Castello Sforzesco) seriously destroyed by the requblican government of Ambrosiana. On entering into the city, however, he felt pressing necessities of the reconstruction. In spite of some opposition, the duke succeeded in persuading the commune that the castle had to be rebuilt for the sake of spectacular appearance of the city. By way of compensation he profited cunningly by the project of erecting a new hospital. For these circumstances see, M. Lazzaroni and A. Muñoz, op. cit, p. 163 and Biagetti, Ospedale, pp. 10 11.

67) According to a certain historian, Burrocco di Monza, Michele da Carcano was appointed "a prescrivere le regole per il buon governo" of the hospital "per le fatiche da esso sostenute in farlo ereggere" (P.M. Sevesi, "Il Beato Michele da Carcano e l’Ospedale Maggiore di Milano", Lomellina, Vigevano, 1935). Cf. Biagetti, Ospedale, pp. $20 \sim 21$.

68) The construction directed by Filarete was brought to a halt in the summer of 1465, when he abandoned his position as a primary architect rejeting to receive a part of his salary. See, M. Lazzaroni and A. Muñoz, op. cit, pp. $195 \mathrm{ff}$.

69) The letter, dated March 30, 1466 and published by Sevesi, reads: “...prego che vogliate favorire cum opere et cum parole et cum veri et evidenti effecti che quello hospitale si finischa $\cdots$ perchè sento, se la vostra Celsitudine

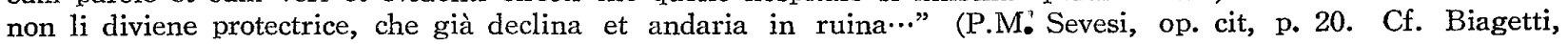
Ospedale, p. 16).

70) “...nel cinquantasei poso mille quatrocento anni dal parto salutifero de la Virgine, Francesco Sforza, signore de singulare virtute, ...si prese etiam questa cura de reformare questi hospitali. Et havendo col senato suo et tutti li magistrati coadunato ancora la nobilità et principali ordini dela città $\cdots$ et specialmente li osservanti de sancto Francesco, per la quale alhora compareva frate Michele da Carcano, confortando con le predicatione sue questa reformatione et molto li era creduto per la sanctità dela vita, disputata et ben maturata questa materia, dela quale de alchuni anni anni in ante el populo ne aveva facto mentione cum papa Nicola quinto, et obtenuta la reformatione et unione et electo al tractare le cose loro per più commodità.." (Gilino, op. cit, Italian edition, chapter V, 'Da unde ha pigliato Irincipio la reformatione', Spinelli, op. cit, p. 387). "...anno quinouagesi mosextio post mille quadringentosque a uirginis partu Franciscus Sfortia singularis uirtutis princeps $\cdots$ hanc quoque restitue $\mathrm{di}$ in pristina pietatis opera has hospitalis domos curam suscepit ad quam rem cum senatum ac reliquos magistratus stque insuper nobilitatis quoque mediolanensis omniumque ciuitatis ordinum concilium collegisset : ac preter eos omnium religionum quæ Mediolani erant: in primisque illius quæ aub sancti Francisci titulo regulare obseruationem prositetur. In qua tunc pr cipue Michaelis Carchani uirtusenitebat cuius uehe mentissimæ conciones ad has reformandas domos populum inflammabant: primarios adhibuisset: re mature tractata atque his repetitis quæe ante Mediolanensis populus sub pontefice Nicolao quinto mouere atque agere ceperat in idomnium sententiis itum est ut nulla re facilius in locis de quibus dictum est..." (Gilino, op. cit, Latin edition, chapter VI, 'Vnde riformatio initium coeperit'). 


\section{オスペダーレ・マッジョーレと十字形病㮴を的つ \\ ロンバルディアの病院に関する研究（梗概）}

正会員日高 健一郎*

オスペダーレ・マッジョーレの十字形病棟にはいくつ かの先例がみられる。1450 年に着工されたマントヴっ の病院はその一つで, ゴンツァガ家とスフォルツァ家の 密接な関係, およびフィラレーテ自身による記述から， このサン・レオナルド病院がミラノのオスペダーレ・マ ッジョーレに少なから始影を及ぼしたことが考えられ る。これより以前, 1449 年にパヴィアでは正方形の外 周建築に内接するギリシャ十字形の病棟をもつサン・マ ッテオ病院が着工されたが, この病院は当時知名度の高 かったトスカーナの病院, 特にフィレンツェのサンタ・ マリア・ヌォーヴケ病院, シェナのサンタ・マリア・デ ッラ・スカーラ病院とは全く異った新しい十字形構成を 有するものであった。このサン・マッテオ病院の建設用 地を提供したのはミラノ候, フランチェスコ・スフォル ツァであり,フィラレーテもパヴィアに率在した経験を もつことから，オネペダーレ・マッジョーレに対するそ の影響力は大きかったと思われる。十字形病棟をもつ口 ンバルディアの病院のうち, 最初の例はブレーシャのサ ン・ルカ病院（現存せず）であるが，建物は長くT字形

*. 日本学術振興会浖励研究買 (東京大学)

(昭和 54 年 3 月 31 日本稿受理 -討諭期限昭和 55 年 3 月末日)
のままとどまり，後になって第四棟が補われた。1451〜 2 年に着工されたクレモーナのサンタ・マリア・デッラ ・ピエタ病院はやはり十字形病棟の形跡をとどめている が，㧓児養育院が新しい要素として当初から付加され， 十字形構成を複雑化している点でオスペダーレ・マッジ ョーレの重要な先例をなすといえる。パヴィア,ブレー シャ,クレモーナの各病院はすべてそれ以前の都市内の 小病院を統合してつくられた「大病院」であり, 15 世紀 半ばの修道会勢力による病院設立の気運が結実したもの である。ミラノのオスペダーレ・マッジョーレもほぼ同 様の設立事情をもち，ミケケーレ・ダ・カルカーノがその 計画, 建設を通して 重要な貢献をした。16 世紀初頭の ジリーノの冊子 (無題) ではオスペダーレ・マッジョー レの立案者, 建設者として, ミラノ候, フランチェスコ ・スフォルッォとともにこのフランチェスコ会修道士。 ミケーレ・ダ・カルカーノの名があげられ，フィラレー テの名は付記されていない。これらの点から，オスペダ ーレ・マッジョーレに扫ける十字形病棟の計画は, フィ ラレーテの独創にかかるものであるといらよりは，ロン バルディアのほぼ同時期の先例からごく自然に導入され た要素であると考えるのが適当である。 